\title{
MUSIC IN THE RHYTHM OF WAR: \\ Othmar Schoeck and the \\ Beginning of Whitman-Music in the German-Speaking Countries
}

WERNER GRÜNZWEIG

I.

DESPITE THE PROFOUND EARLY INTEREST in Whitman shown by the public at large, composers in the German-speaking countries were late in discovering Whitman texts for vocal music. It may hardly come as a surprise that writers preceded composers in their interest for Whitman. ${ }^{1}$ The fact, however, that Whitman was neglected in the first decades of the twentieth century when "free verse" poetry played an important role in text-based compositions and music itself assumed "prose" character (i.e., was no longer structured in regular units), is not so easily comprehensible. Also, the tradition of lied and Gesang was still unbroken by $1900 .^{2}$ As shown by the work of Arnold Schoenberg, lied and Gesang were even supposed to pave the way to a completely new musical language: the verbal text was designed to keep music, deprived of its old foundations such as tonality, from aesthetic disintegration. Neither was there any literary chauvinism: German-language composers liked to set foreign poetry to music as long as translations with a sufficient quality were available (such as the Baudelaire poems translated by Stefan George). Whitman's Leaves of Grass was available in satisfactory translations such as that of Johannes Schlaf, which was known in the Viennese music circles around Arnold Schoenberg. ${ }^{3}$ Thus, concerns with regard to Whitman's literary reputation or the suitability of his texts for musical settings could not have been an obstacle.

Though there were earlier works such as the cycle Vom ewigen Leben (Of Life Eternal, 1924) by the Austrian composer Franz Schreker (1878-1934), that used Whitman poems in a universal, "transcendentalist" fashion (in this case "Roots and Leaves Themselves Alone" and "A child said What is the grass?"), the majority of Whitman compositions in the German-speaking countries do not appear until after 1945, and their orientation is, for the most part, political. Why composers saw Whitman mainly as a political poet cannot yet be fully explained. It is certain, however, that Whitman was understood as the poet of war (and of grief over war) and that the use of his poems for musical settings suggests a 
political confession on the part of the composers. This movement away from "L'art pour l'art" positions - which even Schoenberg, one of the most radical champions of "absolute" music, joined with his A Survivor from Warsaw (1947)-occurred in reaction to the unimaginable horror of Nazi crimes. The two major Whitman compositions from this period are Paul Hindemith's When Lilacs Last in the Dooryard Bloom'd. A Requiem "For Those We Love" (1946) for chorus, orchestra and soloists, which the composer wrote while still in American exile, as well as the 1. Symphonie (Versuch eines Requiems) (First Symphony [Attempt at a Requiem], 1947-48) by the German antifascist composer Karl Amadeus Hartmann, who adapted texts from "I Sit and Look Out," "When Lilacs Last in the Dooryard Bloom'd," "Tears" and "Pensive on Her Dead Gazing."

There is, however, one early composer who did interpret Whitman politically, and whose Whitman composition therefore commands special attention and interest. With his 1915 work entitled Trommelschläge (Drum-Taps) for mixed chorus and full orchestra (the text actually consists only of the poem "Beat! Beat! Drums!" from the cycle DrumTaps), Othmar Schoeck (1886-1957), a Swiss composer, made a radical political statement. Schoeck was the only composer during World War I to set a Whitman poem to music. Given Schoeck's career, this was rather surprising: aesthetically, he had been a traditionalist up to that point and the radicality of both text and composition of Trommelschläge marked a striking departure from his previous oeuvre. As a late representative of the romantic lied tradition, Schoeck had set to music such German-speaking poets as Eichendorff, Mörike, Lenau, Goethe and Keller - the "old masters." Moreover, the history of composers to whose oeuvre the lied was central (it was merely an experimental genre for Schoenberg and his school) had come to a close with the end of the nineteenth century.

Traditionally, the lied expressed the voice of an integral although occasionally endangered individual. Schoeck's Trommelschläge, however, has little to do with this tradition. Rather, the work (not only Whitman's text itself, but also the compositional means used) threatened the traditional conception of the individual. The notion of individualism was replaced by the extreme anti-romanticism of mass experience. ${ }^{4}$ The dynamics of the masses in the first modern metropoles form one of the central human experiences at the beginning of the twentieth century, one of the experiential shocks which many intellectuals (like Gustave Le Bon, Sigmund Freud, Elias Canetti and Hermann Broch) attempted to investigate. The profound effect that this experience had on human sensibility explains the relevancy and modernity of Whitman's "en masse" rhetoric. Typical bourgeois values such as selfrestraint and autonomy (often connected with chamber music and the 
lied) are suspended and replaced by Schoeck's masterful sign of threat and destruction. The uncontrollable mass movement represented by the war made it impossible to keep the war out of the living rooms and salons of the bourgeoisie. No longer was there a possibility for a middleof-the-road position between war and peace. Schoeck's composition forced his bourgeois audience to take a stand: for or against the war.

\section{II.}

A look at the first page of Schoeck's score (see facsimile on back cover) reveals immediately that he places the late-romantic orchestra, disfigured by oversized percussion, around the main rhythm, a military drum rhythm led by no fewer than six tenor drums ("Rührtrommeln"). Thus, in a truly expressionist manner, the orchestra becomes one gigantic drum. Schoeck directed his attention especially to the rhythmization of the text. In the traditional stanzaic lied it followed more or less mechanically the original pattern, whereas in Schoeck's Trommelschläge it is directed toward highest expressivity as will be shown in the following example.

The simplest rhythmization of the first line-which would also be the most natural way to recite it-is:

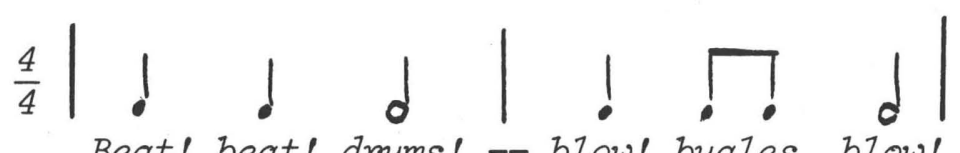

Beat! beat! drums! -- blow! bugles, blow!

The German word for "drums" ("Trommel") has two syllables. In order to maintain the caesura after "drums!", the rhythmization would have to be altered a little:

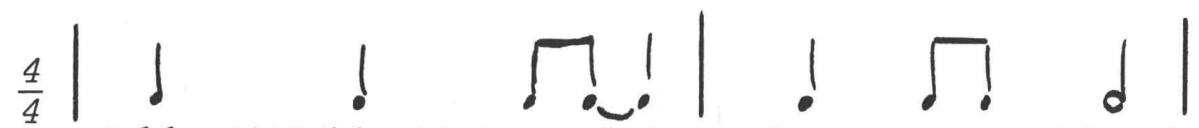
Schlagt! Schlagt! Trommeln! -- Blast, Hörner, blast!

In comparison to this, Schoeck violates the "natural" way of distributing stressed and unstressed syllables which results in a rhythmical antithesis to the basic rhythm of the drums:

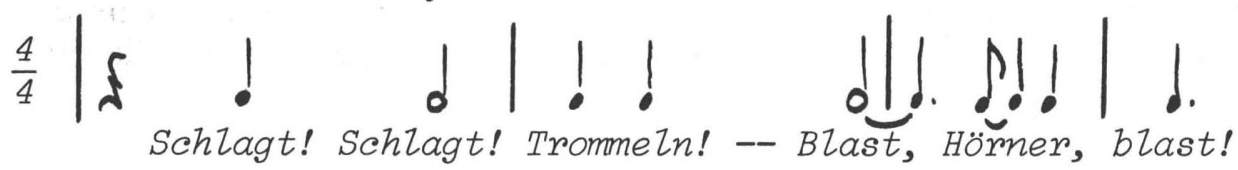


Schoeck does not aim at the most natural, "flowing" declamation, but preserves the expressiveness of the text by retaining the striking rhythmic characteristics that John Schwiebert has recently analyzed in detail. $^{5}$ Schoeck does not try to adjust the uneven meters; instead, he highlights single words that he thinks to be of special expressivity. The stress on the second "Schlagt!" emphasizes this call because it contradicts a more conventional declamation. The last word of the line, "blast!," receives a special stress, because it is placed on the first beat of a bar. We can see an increase of emphasis towards the end of the line which results in a very dynamic beginning of the whole piece. Schwiebert's analysis of the poem holds true not only for Whitman's verbal text, but for Schoeck's compositional technique as well:

The poem is about a world thrown off its center, in which the sounds of war drown out the activities of peace. The destabilizing power of war clashes with the stability of peace, and this conflict resonates in the tension between free (i.e., destabilizing) and traditional (stable) verse elements. ${ }^{6}$

Another of Schoeck's techniques is the acceleration and slowing down of the declamation. The first part of the second line, "Durch Fenster brecht und Türen" (literally translated: "Through windows burst and doors") is rhythmized as follows (adding up to three quarter notes and one eighth note):

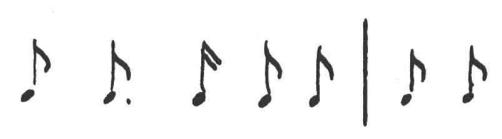

whereas the following "mit unbarmherziger Gewalt" ("with ruthless force") is twice as slow (eight quarter notes):

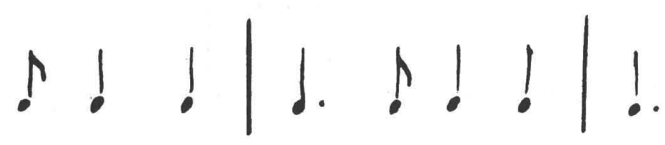

In Schoeck's music, the fast tempo represents the fast pace of destruction, while the slower tempo represents the unstoppable violence of the war. During all of this, the basic rhythm of the drums remains unchanged which again results in strong tensions between the two "layers" of the music: 


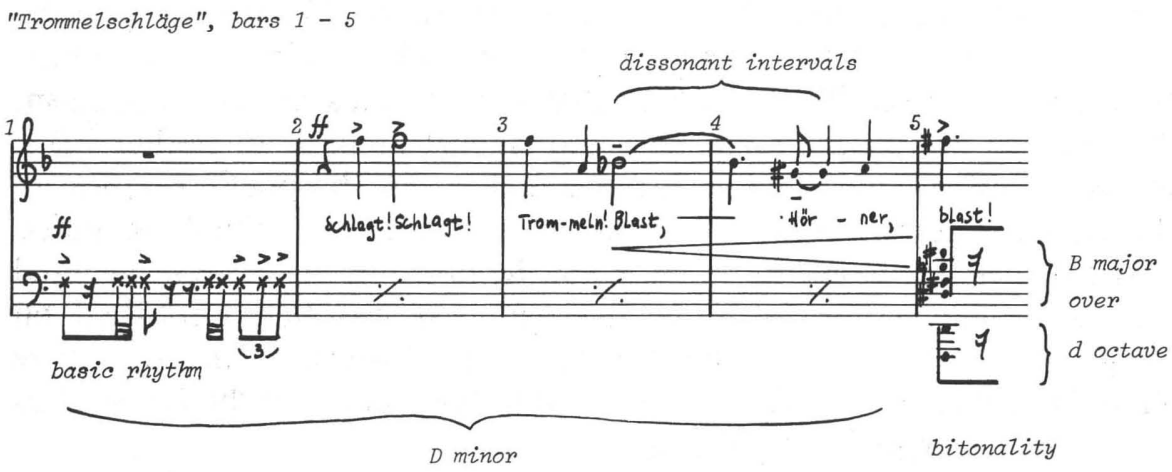

From the point of view of harmony, the beginning consists of perfect fifths and fourths around the central tone $D$. When the chorus first enters, the as yet incomplete harmony turns into $D$ minor which is also the main key of the work as a whole. But already in bars 3-4, Schoeck starts to disturb this quasi-archaic state of rest by powerful dissonances between chorus and accompaniment (minor second, major seventh and minor ninth). This musical disruption is for him an image of the disruption of bourgeois life by the war noise which, in turn, signifies war itself: for the first time such a dissonance occurs in bar 3 ("Blow!"), then at "Hör[ner]" and then, startlingly powerful, on "blow" (bar 5) where $D$ minor is disrupted and replaced by a bitonal construction ( $B$ major over $D$ minor). This bitonal effect is particularly aggressive because the $D$-sharp of $B$ major is strongly dissonant with the $D$ of the base. It appears in the bar in which the war noise breaks into the houses ("durch Fenster brecht und Türen"; "through the windows - through doors - burst like a ruthless force").

One could continue this analysis at length, but these few examples will suffice to point out how music itself can assume meaning and how Whitman's text could lead the composer to extreme expressionistic methods. Schoeck's method was that of exaggerating compositional means, but he also worked with direct and indirect musical shock effects such as sharp dissonances, bitonality, shouting by the chorus singers, etc. Instead of the more neutral title of Trommelschläge, Schoeck's original choice of title had been "Aufbruch zum Kriege" ("Departure for War"). For the composer, the beating of the drums signalled the call to war, a war which, at that time, was welcomed and even fervently awaited by many people. The question remains why Schoeck, from all of Whitman's war poems, chose "Beat! Beat! Drums!" for his composition. In the eyes of many interpreters, this poem represents Whitman's radical pro-war attitude which was frequently criticized in the twentieth 
century. But was it only this attitude that struck his readers as inconsistent with the general humanistic standard of Whitman's poetry? Probably not. It rather seems to be the enthusiastic tone in which Whitman expressed his call to war that was so shocking, an enthusiasm that seemed to lack common sense and critical thought altogether. ${ }^{7}$ But we have to distinguish between a poem that was the poet's reaction to the disastrous battle of Bull Run and the poem that was finally included in the Drum-Taps collection. It was not the poem itself that was changed so much (only a few words of the text that was first published on September 24, 1861, in the Boston Daily Evening Transcript were altered) ${ }^{8}$ rather it was placing the poem in the context of the Drum-Taps cluster that changed its meaning.

For Whitman, "Beat! Beat! Drums!" originally seems to have been a "functional text" that was consequently published in a newspaper. Gay Wilson Allen called it "Whitman's own editorial contribution." That Whitman did not change the poem later on (whereas he continually changed many other poems in Leaves of Grass) may show that he considered it to be a historically significant document. He probably did not want to conceal the fanatical element, because for him it represented an integral aspect of the war. And, of course, in Drum-Taps it had its counterbalance in the poems of compassion. The tenderness of "The Wound-Dresser," the admission that the enemy is "a man divine as myself" in "Reconciliation," the mutation of the "Terrible drums" and bugles into instruments of consolation in "Dirge for Two Veterans"through all this the violence against the old, against mothers and children is neutralized. There can be no doubt about which side Whitman was on because for the poet-as Katherine Kinney argues in a recent analysis of "Beat! Beat! Drums!"-the condemnation of war signalled not only a humanistic position but was the basis of Whitman's political thinking as well: "The maternal bond of love, so basic to Whitman's conception of democracy and society, is rendered silent and marginal by the war, unable to oppose the forceful subsuming of individual lives." 10

Schoeck took up this incongruency between the over-optimistic tone of the poem and the cruelties that it expresses, and he reinforced it through compositional means: although many of his ingredients are traditional in military music, he exaggerated these affirmative, pro-war elements - as with the drum rhythm which pervades almost the whole piece. As a result, the effect of this "call" is not one of incitement; rather, it acoustically buries the audience by its force. Without actually having to say so, this music-by means of its exaggeration - functions as a politically motivated épater le bourgeois in order to provoke protest. 
When Schoeck composed Trommelschläge, he was the director of the Zurich Lehrergesangsverein (Teachers' Choral Society). Thus, he was not only established in the world of music but also had a respected social position. His letter to his friend Hermann Hesse (August 24, 1915) demonstrates that he was conscious of how he had endangered his social position when he attacked the hypocritical and deceptive front of bourgeois safety in neutral Switzerland with his composition: "Incidentally, I have vented my whole anger over our present situation in a choral work. This piece may break my neck and finish off my position in Zurich."11

Today, in a period of the consolidation of bourgeois lifestyle in which artists merely desire to attract attention, it is hard to understand how much the bourgeoisie once recognized itself in art and to what degree it identified with artistic productions, mainly in an attempt to make up for or cover up deficits in that realm. The Musikvereine (music societies) of the nineteenth century rose together with the economic progress of the bourgeoisie and were therefore indicative of its political emancipation. Just as a book by Salman Rushdie can provoke a whole religious community today, an offense against the accepted rules of art at the turn of the century equalled a breach against religion for a whole class (the term Kunstreligion, "art religion," is therefore fully justified).

As a part of this Ersatz-religion, the status of vocal music is particularly critical, combining, as it does, two highly status-related arts: music and literature. ${ }^{12} \mathrm{~A}$ breach against an unwritten "ethic of the symphonic concert" could lead to serious consequences. By combining a "low" literary genre with music written for large orchestra in his Fünf Orchesterlieder nach Ansichtskartentexten von Peter Altenberg, op. 4 (Five orchestral songs using picture postcard texts by Peter Altenberg, 1913), the Viennese composer Alban Berg created a scandal that provoked a heated debate and that was reported throughout Europe and even overseas: the differences of opinion among the various groups in the audience with regard to the relatively harmless, short free-verse poems with their erotic insinuations characteristic of Viennese coffeehouse literature, became so great that people attacked each other with their fists.

Schoeck was spared that sort of a scandal: in contradistinction to Berg, who had not even "legitimized" his musical activity by completing a music academy, Schoeck was able to point to his studies with the famous and widely respected Max Reger. Moreover, as chorus director, he had a strictly defined position in society. However, Schoeck did run into trouble with the chorus itself. During the rehearsals of the work which at that time was still called "Departure for War," the singers protested so violently that the president of the society was forced to ask 
its members "to hold back their critical judgment of the Trommelschläge for the time being and wait for the result of the premiere."13

The concert, in which the premiere of the Trommelschläge was the central event, took place on March 5, 1916 in the Zurich Tonhalle with the famous "Tonhalle-Orchester." Unfortunately we do not know how the audience reacted to the performance, whether with calm restraint or with protests. In an interview conducted several decades later, the composer referred only to the compositional innovation of using a chorus which not only sings but also speaks. ${ }^{14}$ However, newspaper reviews probably reflect certain aspects of the public's reaction.

Hans Reinhart, poet, literary critic and Whitmanite himself, ${ }^{15}$ wrote about the concert in the Winterhurer Tagblatt:

This premiere of a work for mixed chorus and large orchestra has been met with the greatest of expectations. Already the general rehearsal on Saturday taught us, that the Trommelschläge are an ingenious as well as overly audacious achievement. Schoeck, fully out of the spirit of our time, used the cruel and tough hymn introducing the cycle of Drum-Taps translated by Johannes Schlaf with considerable 'poetic license.' Indeed, Schoeck would have probably been unable to find a more suitable text in order to express his indignation, indeed ridicule, of this horrible war of our time than this prelude to the Drum-Taps by Whitman. With his most recent work, Schoeck, whose whole personality (just as the personality of so many other artists) does not tend towards the military, proves clearly that he does not face the events of the day with a cold and indifferent eye. These two sides of Schoeck's personality-the pastoral as well as the martial-were revealed in the course of the powerful, ever intensifying concert evening. ${ }^{16}$

Reinhart's line of argument with regard to the motivation for this work of art, is conspicuously twisted: on the one hand, Schoeck's "personality" is said not to tend toward the "military side," but, on the other hand, the composer supposedly does not take a "cold and indifferent" attitude towards the events: was the critic referring to the war enthusiasm which overcame so many artists and intellectuals on the eve of World War I, because they hoped for a "purge," a collective effort, a new and radical departure? A utopia, which was only revealed as deceptive in view of the unheroic and terrifying mud battle near Verdun? And what exactly was the "spirit of our time"? Possibly the "Call to War" to which Schoeck devoted his composition?

The critic of the respected Neue Zürcher Zeitung, Ernst Isler, expressed himself more clearly:

The poem (Trommelschläge) seems as though created for our war-torn time. With fortissimo on top of a vigorous drum roll, the orchestra takes its course pushing everything else aside, and into this powerful introduction the chorus enters with a vehemency of expression which makes us shudder. Only for a moment, the gigantic five-minute torrent of sounds comes to a standstill, at the point where the dead are mentioned. Then it moves beyond them in order to conclude with doubled force. A crass 
realistic work with unheard of audacity and brutal power which may carry great significance as an episode in the life's work of an artist but which has to remain an episode. ${ }^{17}$

Right from the beginning, Isler attempts to interpret the piece in terms of national Swiss needs, addressing it as music accompanying the times. But in order to justify the liberal claims of his paper and in order not to sound like a mere warmonger, the critic turns the composer of this work into a realist, indeed, a hyperrealist, who presents the war without commenting on it: when Isler writes about a "vehemency" which makes one "shudder," one might think the critic interprets the piece not as expressing enthusiasm for war but as protest against the meaningless massacre-a protest smuggled into the heart of bourgeois representation, the concert hall. At the same time, however, this established critic of a leading newspaper warns the composer not to continue in this direction. The statement that pieces of this kind must "remain an episode" is nothing less than a public threat veiled as aesthetic speculation.

While journalists intentionally used an ambivalent language, the private observations of Feruccio Busoni, a famous composer living in Berlin, are more straightforward and revealing. In a letter to Schoeck, he wrote:

You, in your modest manner, wanted to direct me to the poem in order to explain my impression. To this, I did not reply. Please bear in mind that we have learned (the hard way) that the world is neither strengthened nor ennobled by the incitement of drums and bugles! Whitman's uneducated fanatic tone is not after my heart-But there is a certain power and vibration with regard to the agitation of the masses which one cannot deny him. ${ }^{18}$

Busoni states unequivocally that he interprets both text and music as affirmative with regard to the war. Unlike Reinhart, he unadornedly describes the power of the text and criticizes it mainly for moral reasons, although he does admit its appeal to the masses. As a pacifist, however, such an appeal is suspicious to him. He distrusts mass agitation in general and therefore does not agree with the musical mass organization in Schoeck's Trommelschläge. He does not want to hold up a mirror to his time because, deeply grounded in idealistic positions, he does not want to allow his enemy to dictate the means-drums and bugles. $\mathrm{He}$ fails to understand the extent of the alienating effects achieved by Schoeck through exaggerated compositional means, and he fails to realize the possibility of an inversion of meaning through compositional strategies. Maybe he disliked the use of music for explicit political statements: the saying that music is always several decades behind the other arts seems once more proven true. At that time, of course, another saying, by another poet of war, was not yet known. At the beginning of 
World War II, Bertold Brecht characterized the theory and the function of art that speaks out of Schoeck's Trommelschläge in the following way:

In the dark times

Will there also be songs?

Yes, there will be songs,

About the dark times. ${ }^{19}$

\section{Free University of Berlin}

\section{NOTES}

1 The first German translation of Whitman poems, by the German poet Ferdinand Freiligrath, appeared in 1868; the first book-length translation was published in 1889 . By the late $1880 \mathrm{~s}$, Whitman had already become a significant creative influence on naturalist writing in Germany.

2 In English, a terminological differentiation between lied and Gesang is difficult because there is not even a strict separation in German. The lied is the simpler, more popular vocal piece with regular meters and rhymes, oftentimes composed in stanzas. Starting in 1900, composers addressed as "Gesang" pieces which were more sophisticated in terms both of text and of music, frequently accompanied by orchestra rather than piano and without repetitive sections. In German translation, Whitman's "Song of Myself" is of course referred to as "Gesang von mir selbst," and not "Lied von mir selbst," although the term lied was certainly also used for poetry (e.g., Heinrich Heine's Buch der Lieder published in 1827).

3 One example: the library of the composer Alban Berg (1885-1935) included both Emerson's Essays and Whitman's Grashalme (Leaves of Grass) (cf. Berg papers in the Austrian National Library, F 21 Berg 101/II, f.130). In his Sieben frühe Lieder 1907 (Seven Early Songs), Berg wrote a musical setting for a poem by Johannes Schlaf, and can therefore be said to have been indirectly in touch with the German Whitman-circle. Johannes Schlaf was Germany's foremost Whitmanite; his 1907 translation was the best known of the many German editions of Whitman's works. For further information on Schlaf's extensive international Whitman connections, see Walter Grünzweig, "Collaborators in the Great Cause of Liberty and Fellowship: Whitmania as an Intercultural Phenomenon," Walt Whitman Quarterly Review 5 (Spring 1988), 16-26.

4 One might argue that Trommelschläge, as a choral work, cannot be a lied. However, in this case, the chorus sings almost exclusively unisono, i.e., the composition requires the mass production of one single voice, suggesting de-individualization.

5 John E. Schwiebert, “A Delicate Balance: Whitman's Stanzaic Poems," Walt Whitman Quarterly Review 7 (1990), 119-122. Although Schwiebert analyzed the original version, his analysis - in a modified way-would also be applicable to Schlaf's translation.

6 Schwiebert, 121.

7 Where the enthusiastic tone of this poem comes from can be seen when it is compared with a poem quoted in Gay Wilson Allen, The Solitary Singer: A Critical Biography of Walt Whitman (New York: Macmillan, 1955), 276: In the first version of "I Heard You 
Solemn-Sweet Pipes of the Organ" that was written at about the same time as "Beat! Beat! Drums!" (with which it shares many poetic images), the themes of war and sex came together in one poem:

War-suggesting trumpets, I heard you;

And you I heard beating, you chorus of small and large drums;

You round-lipp'd cannons!-you I heard, thunder-cracking, saluting the frigate from France;

Heart of my love!-you, too, I heard, murmuring low, through one of the wrists around my head-

Heard the pulse of you, when all was still, ringing little bells last night under my ear.

The passionate tone that shapes this poem and brings together war and sexuality, a combination that has become hard to accept for the modern reader, can also be found in "Beat! Beat! Drums!" Maybe this comparison is a little too far-fetched, but judging from the intensity of the poem, does the singer of "Beat! Beat! Drums!" not seem like a deeply disappointed lover who deplores his fate? I agree with John Snyder who sees a strong connection between the "Calamus" poems and the war poetry of Drum-Taps, but I would even include poems like "Beat! Beat! Drums!" that Snyder himself calls "overtly violent" (The Dear Love of Man: Tragic and Lyric Communion in Walt Whitman [The Hague, Paris: Mouton, 1975], 186).

8 Cf. the facsimile reprint in Walt Whitman Review 21 (1975), 44.

9 Allen, 274.

10 Katherine Kinney, "Whitman's 'Word of the Modern' and the First Modern War," Walt Whitman Quarterly Review 7 (1989), 4.

11 Werner Vogel, Othmar Schoeck. Leben und Schriften im Spiegel von Selbstzeugnissen und Zeitgenossenberichten (Zürich: Atlantis, 1976), 98. This and all subsequent translations from the German are my own.

12 That literature and music were the central arts during the nineteenth century and that there were obvious correlations between them is not a new thesis of cultural historiography but an invention of nineteenth century theoreticians who constructed a "Viennese classicism" in music parallel to the "Weimar classicism" in German literature.

13 Vogel [1976], 98.

14 See Werner Vogel, Othmar Schoeck im Gespräch (Zürich: Atlantis, 1965), 147ff.

15 Hans Reinhart, a Swiss writer, belonged to a group of artists in the Swiss city of Winterthur who much revered Whitman. In 1919, on the occasion of Whitman's hundredth birthday, he "greeted" the poet by authoring a "consecreation." See Hans Reinhart, "Weihegru $\beta$ an Walt Whitman," Fahrbuch der literarischen Vereinigung Winterthur (1919), 166.

16 Quoted from Vogel [1976], 100-102. 
17 Quoted from Vogel [1976], 102.

18 Quoted from Vogel [1976], 102.

19 "Spruch" introducing Part II of the "Svendborger Gedichte," a collection of Brecht poems from the Danish exile. Gesammelte Werke 9 (Frankfurt/Main: Suhrkamp, 1967), 641. The words in the German original are as follows: "In den finsteren Zeiten / Wird da auch gesungen werden? / Da wird auch gesungen werden. / Von den finsteren Zeiten." 